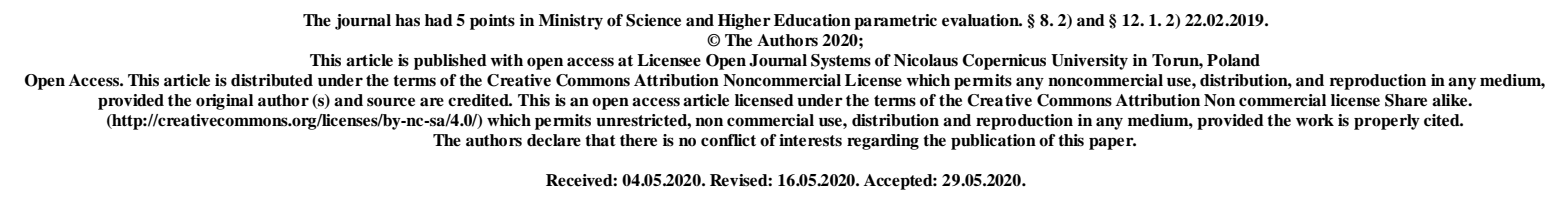

UDC 617.55-007.274-084-092(048.8)

\title{
PATHOGENETIC ASPECTS OF POST-SURGICAL ADHESIONS PREVENTION (REVIEW OF LITERATURE)
}

\author{
M. G. Melnychenko, A. A. Kvashnina
}

\section{Odessa National Medical University, Odessa, Ukraine}

\begin{abstract}
Introduction. It has been established that adhesions in the abdominal cavity are a natural protective and adaptive reaction in response to peritoneal damage, but excessive adhesions are not only a pathological process, but also causes intestinal obstruction in children in $62 \%$.

Purpose: to study the pathogenetic aspects of prevention of surgical adhesions.

Results. A large number of preventive strategies have been proposed, which are aimed at certain adhesion etiopathogenesis zones, such as inflammation and exudation reduction; coagulation cascade inhibition, fibrin matrix and fibrin deposition formation; fibrinolysis process potentiation; fibroblast proliferation inhibition; neoangiogenesis inhibition; free radical oxidation prevention caused by hypoxia; prevention of contact between damaged peritoneal areas.

Conclusions. The problem of prevention of excessive intra-abdominal adhesions remains relevant due to imperfection of the existing variety of methods of prevention and treatment of adhesive intestinal obstruction, and one of the main tasks of its solution in children is to find a sparing and, at the same time, effective way to prevent excessive intraabdominal adhesions at preoperative, intraoperative and postoperative stages.
\end{abstract}


Key words: pathogenetic aspects; prevention; post-surgical adhesions.

\title{
ПАТОГЕНЕТИЧНІ АСПЕКТИ ПРОФІЛАКТИКИ ПІСЛЯОПЕРАЦІЙНОГО СПАЙКОУТВОРЕННЯ (огляД літератури)
}

\author{
М. Г. Мельниченко, А. А. Квашніна
}

\section{Одеський національний медичний університет, м. Одеса, Україна}

\section{Резюме}

Вступ. Встановлено, що спайкоутворення в черевній порожнині - природна захисна і пристосувальна реакція у відповідь на пошкодження очеревини, але надмірне спайкоутворення $є$ не тільки патологічним процесом, а i в $62 \%$ спричиняє непрохідність кишечника у дітей.

Мета: вивчення патогенетичних аспектів профілактики післяопераційного спайкоутворення.

Результати. Було запропоновано велику кількість превентивних стратегій, що направлені на окремі ділянки етіопатогенезу спайкоутворення, це зменшення явищ запалення та ексудації; пригнічення коагуляційного каскаду, формування фібринової матриці та депозиції фібрину; потенціювання процесу фібринолізу; інгібування проліферації фібробластів; пригнічення неоангіогенезу; профілактика вільнорадикального окиснення у наслідок гіпоксії; попередження контакту між пошкодженими ділянками очеревини.

\begin{abstract}
Висновки. Проблема профілактики надмірного інтраабдомінального спайкоутворення залишається актуальною в силу недосконалості існуючого різноманіття способів профілактики і лікування спайкової непрохідності кишечника, а одним з основних завдань іï рішення у дітей є вишукування щадного i, разом 3 тим, ефективного способу профілактики надмірного процесу інтраабдомінального спайкоутворення на доопераційному, інтра- та післяопераційному етапах.
\end{abstract}

Ключові слова: патогенетичні аспекти; профілактика; післяопераційне спайкоутворення. 


\title{
ПАТОГЕНЕТИЧЕСКИЕ АСПЕКТЫ ПРОФИЛАКТИКИ ПОСЛЕОПЕРАЦИОННОГО СПАЙКООБРАЗОВАНИЯ (обзор ЛИТераТУрЫ)
}

\author{
М. Г. Мельниченко, А. А. Квашенина
}

\section{Одесский национальный медицинский университет, г. Одесса, Украина}

\section{Резюме}

Введение. Установлено, что спайкообразование в брюшной полости естественная защитная и приспособительная реакция в ответ на повреждение брюшины, но чрезмерное спайкообразование является не только патологическим процессом, но и в 62 \% приводит к непроходимости кишечника у детей.

Цель: изучение патогенетических аспектов профилактики послеоперационного спайкообразования.

Результаты. Было предложено большое количество превентивных стратегий, направленных на отдельные участки этиопатогенеза спайкообразования, это уменьшение явлений воспаления и экссудации; угнетение коагуляционного каскада, формирование фибриновой матрицы и депозиции фибрина; потенцирование процесса фибринолиза; ингибирование пролиферации фибробластов; угнетение неоангиогенеза; профилактика свободнорадикального окисления вследствие гипоксии; предупреждения контакта между поврежденными участками брюшины.

Выводы. Проблема профилактики интраабдоминального спайкообразования остается актуальной в силу несовершенства существующего многообразия способов профилактики и лечения спаечной непроходимости кишечника, а одной из основных задач ее решения у детей является поиск щадящего и, вместе с тем, эффективного способа профилактики чрезмерного процесса интраабдоминального спайкообразования на дооперационном, интра- и послеоперационном этапах.

Ключевые слова: патогенетические аспекты; профілактика; послеоперационное спайкообразования.

Introduction. At the present stage, it is considered that adhesions in the abdominal cavity are a natural protective and adaptive reaction in response to peritoneal damage $[1,2,3$, 4]. However, excessive adhesions are not only a pathological process, but it causes intestinal obstruction in children in $62 \%$ cases and leads to disability $[5,6]$. 
According to the scientific literature data, the concept of trauma of the abdominal cavity serous lining includes both its mechanical damage during surgery and infectious effect during inflammation. The abdominal injury is caused by its opening (dissection, damage to the mesothelium with tools, swabs, napkins), exposure to talc, concentrated antibiotics, other foreign bodies, and exposure of the peritoneum to the external environmental air [7]. Various chemical agents (alcohol, iodine, hot saline, Dimexidum), which cause aseptic inflammation and lead to the development of perivisceral adhesions, also render a traumatic effect [8]. The use of drainages, tampons, which are essentially foreign bodies, also contributes to the development of adhesions [9]. Omentectomy also contributes to the strengthening of adhesions and depression of fibrinolytic activity in the abdominal cavity [7].

Many principles of primary prevention of adhesions are generally accepted in the surgical practice. These measures, for the first time, deal with the minimization of peritoneal injury, because this effect is the trigger of the fibrin matrix formation, which is the basis for adhesions. That is, improvement of surgical techniques, careful treatment of tissues to reduce abdominal trauma are important measures to prevent adhesions.

The aim of the study: examination of pathogenetic aspects of post-surgical adhesions prevention.

The main principles of the surgeon's actions during abdominal interventions, which should contribute to the prevention of adhesions are as follows:

— careful handling with abdominal tissues;

— use of microsurgical equipment, tools;

— minimization of tissue manipulation, especially outside the direct intervention area;

— constant irrigation to prevent peritoneal dehydration;

— thorough hemostasis, removal of blood clots;

— minimization of electrocoagulation usage;

— use of post-surgical drainage;

— preventing foreign bodies from entering the abdominal cavity;

- use of atraumatic biocompatible non-reactogenic suture material $[1,4,10,11,12]$.

Without doubt, today the use of mini-invasive surgical access is one of the principal means of abdominal tissues sparing and reducing trauma to the peritoneal surfaces. But although this approach significantly reduces the severity of intra-abdominal adhesions and its complications, it does not solve the problem $[6,10]$. The factors which have a protective effect on adhesions during laparoscopic interventions in comparison with laparotomy include: less trauma to the parietal peritoneum, closed moist environment that prevents from drying of 
peritoneal surfaces, decreased bleeding, less manipulation outside the direct intervention area, more rapid restoration of the intestinal motor function at the postoperative period $[2,3]$. However, the large prospective studies revealed that the introduction of laparoscopy did not reveal a significant reduction in diseases caused by adhesions [10]. Besides, despite the traditional view of the impact of these aspects of surgical technique on adhesions, the available and published clinical evidence of the different surgical techniques effectiveness is not sufficient for clear-cut clinical recommendations and guidelines, the results of many studies are conflicting [8].

According to many studies data, minimally invasive interventions are accompanied by independent factors that provoke adhesions.

In particular, the increase in intraperitoneal pressure, the presence of pneumo- or carboxyperitoneum, decreased perfusion of the intestinal wall promote adhesiogenesis [13].

Careful suturing of parietal peritoneal defects at the final stage of abdominal interventions has traditionally been considered essential considering adhesions formation before the surgical scar. But current data indicate that there are no advantages of this approach, and do not even recommend peritoneal suturing, because this stage does not provide significant benefits, but prolongs duration of the operation [14].

A great series of large-scale studies on the influence of various factors during laparoscopy on adhesions was conducted by scientists from Belgium on a mouse model. According to experimental data, the nature of the gas used during laparoscopy causes an inflammatory response from the mesothelium. Carboxyperitoneum has local and systemic effects: acidosis, hypothermia, inhibition of microcirculation and tissue metabolism. In particular, the use of $\mathrm{CO}_{2}$ in comparison with helium causes a lesser tissue reaction, which is manifested in lower expression of $\alpha$-macroglobulin and tumor necrosis factor $[4,7,13]$.

The formation of post-surgical adhesions depends on the duration of pneumoperitoneum, temperature and pressure during insufflation. The response of the damaged peritoneal mesothelium is also affected by the temperature and relative humidity of the gas. Warm and humidified carbon dioxide, compared with cold and dry, reduces the formation of $\mathrm{TNFa}$, lymphocyte migration and the total duration of inflammation in the experiment [13]. The influence of the composition of insufflated gas, in particular the oxygen content on the intensity of adhesions has also been proved [15]. Adhesions were reduced by the addition of oxygen during making carboxyperitoneum, which can be considered as confirmation of mesothelial hypoxia as a provoking factor of adhesiogenesis. 
Besides, despite less trauma to the parietal peritoneum, with insufficient mastery of endoscopic surgical techniques, or in case of technical problems, much greater injury to the visceral peritoneum is possible, and, as a consequence, the formation of viscero-visceral adhesions, which often lead to clinically significant consequences.

The use of laser surgery also significantly reduces post-surgical adhesions due to accurate dissection, providing thorough hemostasis and reducing the duration of the operation. The monopolar coagulation is associated with a greater adhesiogenic effect compared to the bipolar one [8].

At the moment, the effect of abdominal lavage on intra-abdominal adhesions remains controversial. But the protective effect of dosed hypothermia on the processes of adhesions in the experiment is proved. For instance, the introduction into the abdominal cavity of saline cooled to 15 degrees leads to a significant increase in tPA activity and a decrease in the adhesive index in experimental animals $[16,17,18]$.

However, most of these studies do not have a high level of evidence. There are few studies that would highlight the features of preventive measures in pediatric surgery.

Taking into consideration a great number of pathogenetic factors and pathophysiological ways underlying peritoneal adhesions and the considerable time during which the search for a solution of this problem, a number of preventive strategies directed at specific areas of adhesion etiopathogenesis have been proposed, such as:

1) reduction of inflammation and exudation;

2) inhibition of the coagulation cascade, formation of the fibrin matrix and fibrin deposition;

3) potentiation of the fibrinolysis process;

4) inhibition of fibroblast proliferation;

5) inhibition of neoangiogenesis;

6) prevention of free radical oxidation caused by hypoxia;

7) prevention of contact between damaged areas of the peritoneum.

Let's take a look at some factors.

The prospect of adhesions prevention directed to inhibition of proinflammatory biologically active substances action has rich history. The effects of nonsteroidal antiinflammatory drugs (NSAIDs) and glucocorticoid hormones have been extensively studied among drugs aimed at inhibiting exudation and inflammation. Attempts of NSAIDs use to prevent adhesions have a long experience. Drugs of this group inhibited the formation of adhesions in many, though not all experimental studies. However, their use in clinical practice 
has not been widely used due to the risk of bleeding. In modern studies, the activity of gene expression, the mechanism of this action has been studied. In particular, Wei et al. [19] demonstrated that selective cyclooxygenase-2 (COX-2) inhibitors, the gene of which is activated by hypoxia, reduce adhesions by inhibiting fibroblast growth factor and TGF- $\beta$ expression but do not affect angiogenesis [19].

Corticosteroids also have a prophylactic effect on the formation of surgical adhesions in vivo and in vitro by stabilizing vascular membranes, reducing the formation and release of pro-inflammatory cytokines and fibroblast proliferation. However, these drugs, despite the long experience of the study, also did not find widespread use due to side effects, including immunosuppression and impaired wound healing $[8,9,20]$.

There are studies on the effectiveness of the antiemetic drug Aprepitant, which by mechanism of action is a selective antagonist of neurokinin 1 and substance $\mathrm{P}$, which act as key proinflammatory mediators. Its intraperitoneal use to prevent adhesions has even been approved by FDA [21].

The agents aimed at combating the formation and deposition of fibrin are used most often. First of all, it is intraoperative lavage of the abdominal cavity, which leads to dissolution and mechanical washing out of exudate. Secondly, the use of anticoagulants (eg, heparin solution), but the results of their use in experiment and clinical practice have shown controversial results [20]. The effect of abdominal lavage remains controversial too. According to recent studies by Jarosław Cwaliński et al. (2016), abdominal lavage with saline leads to a significant increase in PAI-1 and interleukin-6 activity, stimulation of fibroblast proliferation, which are recognized factors in the peritoneal adhesions formation [16].

The proven pathophysiological basis of pathological intra-abdominal adhesions is the imbalance of fibrin and fibrinolysis formation due to fibrinolysis inhibition during surgery $[10,14]$. Accordingly, the activation of the fibrinolytic link seems to be the most pathogenetically justified way to prevent pathological adhesions. The most obvious way is the intraperitoneal use of fibrinolytics: streto- and urokinases, hyaluronidase, chymotrypsin, trypsin, pepsin, which were effective in animal studies, but data on the effectiveness and safety of their clinical use are insufficient. In particular, there is evidence of an increased risk of delayed surgical bleedings [1, 20, 22].

One of the most widely studied anti-adhesive agent that has demonstrated efficacy is recombinant tPA. Experimental data indicate a preventive effect of human recombinant tPA on the formation of post-surgical adhesions in different methods of intraperitoneal use and in 
the composition of various drugs, without impaired wound healing or anastomoses, or increased risk of hemorrhage [23].

An example of the other strategy of stimulating the synthesis of proper fibrinolytic factors is the use of the substance $\mathrm{P}$ proinflammatory peptide antagonist. When blocking the substance $\mathrm{P}$ binding with the neurokinin 1 receptor $(\mathrm{NK}-1 \mathrm{R})$, the formation of adhesions was significantly inhibited. There was an increase in the formation of matrix tPA RNA, an increase in the concentration of plasminogen tissue activator in the peritoneal fluid [15]. Increased peritoneal fibrinolytic activity can be achieved by the use of HMG-Co-A reductase inhibitors - statins group drugs. The use of this group of drugs demonstrated anti-adhesive efficacy in both intraperitoneal and systemic use [2, 24].

Promising results have also been obtained with the intraperitoneal use of activated protein $\mathrm{C}$, which has fibrinolytic and anti-inflammatory properties [25].

Attempts to reduce adhesions by inhibiting neoangiogenesis look an advanced research direction, but convincing data on the effectiveness and safety of their clinical use are not currently available. The use of TNP-470 and endothelial growth factor antagonists reduced post-surgical adhesions after laparotomy in mice. The efficacy of anti-PIGF and antiVEGFR1 antibodies has been demonstrated in a laparoscopic model [23].

In recent years, the direction of adhesive complications prevention is developing not only by suppressing and stimulating the biochemical activity of one or another pathogenetic factor, but also by modifying the activity of corresponding genes.

Taking into account such peculiarities of post-surgical adhesions as short development time (several days after surgery) and limited pathological process of the abdominal cavity, this process is a good target for gene therapy using non-integrated vector systems, the creation and use of which are technically simpler. Such vectors can be applied locally at the end of the intervention and the short time of their genes expression is sufficient to modify the disrupted molecular interactions (eg: inhibition of tPA, increased activity of PAI-1, TGF- $\beta 1$, HIF-1a, etc.). Although this direction is still in its nascent condition, the first results look promising.

The pathogenetically justified goal for modification is usually the regulation of tPA/PAI-1 balance to the direction of enhanced fibrinolysis. So, in the works of Atta et al. [26], an adenoviral vector encoding human tPA was used. Another example of a method of genetically modifying fibrin deposition activity to prevent adhesion is a cationic polymer containing siRNA to PAI-1 and HIF-1a, the expression of which leads to inhibition of the activity of the appropriate genes. The reduction in adhesions in the experimental study of these structures was $34 \%$ and $52 \%$, respectively [23]. 
The adenoviral vector with the streptokinase transgene revealed the greatest efficiency, the use of which revealed that adhesions were suppressed by $62 \%$ compared to the control [2]. A sufficient success of these preventive strategies suggests that due to the multifactorial pathogenesis, effective prevention of adhesions requires a comprehensive impact on various parts of this process. In particular, a combination of hemotherapy aimed at simultaneous activation of fibrinolysis and fibrinogenesis inhibition is a promising direction.

Among the measures aimed at control of hypoxia and oxidative stress, the formation of active oxygen species and free radical oxidation during laparoscopy has been proven [2]. Antioxidant factors such as superoxide dismutase, catalase and trimetazidine reduce the formation of adhesions in various experimental models. The action of active oxygen forms has a cytotoxic effect on mesothelial cells and leads to apoptosis [27]. Accordingly, this mechanism contributes to further damage to the peritoneum and stimulates adhesiogenesis. There are no data on the use of this strategy in human patients during laparotomy or laparoscopy.

Besides of the influence on the activity of factors that are direct parts of the pathogenetic chain of adhesions, the influence of many other biologically active substances has been studied. In particular, reduced estrogen levels reduce adhesions formation like the use of gonadotropin-releasing hormone (GRH) agonists. The action of these factors is probably based on the fibroblast and endothelial growth factors action modulation, the coagulation cascade inhibition. In addition, there is evidence of clinical efficacy of GRH analogues in the treatment of chronic pelvic pain syndrome and endometriosis $[6,20]$.

It should be noted that most of these studies are based on data obtained from animal models, which have demonstrated the effectiveness of fibrinolytics, steroids, calcium channel blockers, antioxidants, statins, angiogenesis inhibitors etc. But sufficient data on the clinical effectiveness of these factors have not yet been obtained.

Besides of above said, one of the fundamental issues is to determine the indications to surgical treatment of adhesive intestinal obstruction (AIO) due to peritoneal adhesions and its terms. According to most studies and recommendations of the Bologna guideline for the treatment of AIO from the World Society of Emergency Surgery [10, 27], the conservative treatment and dynamic monitoring of adult patients with intestinal obstruction can be safely carried out for 72 hours, in the absence of strangulation. Not only diagnostic but also therapeutic effect from the use of hyperosmolar water-soluble contrast passage in the gastrointestinal tract (mainly gastrografin) was demonstrated. The application of such an approach in the pediatric practice has no recommendations of such a level of evidence, but 
previous results are similar $[18,19,22]$. It should be noted that reliable clinical and diagnostic criteria for strangulation have not yet been identified, which complicates the use of these recommendations in the real clinical situation, and therefore requires follow-up study. So, the only clinical situation in which the safe conservative treatment for a sufficiently long time period can be definitely recommended is clinical and radiological signs of partial AIO in the patient.

The method and extent of surgery for AIO remain unclear. At present, the most convincing data support the recommendations to separate only adhesions, which is the cause of obstruction, without extensive adhesiolysis, which did not show clinical benefits, but significantly increases the intervention time and the risk of intraoperative complications [10]. Sufficient data have been accumulated to recommend the use of laparoscopy in the treatment of AIO only in case if the operating surgeon has good practical skills. Also, the application of pneumoperitoneum by the open way can significantly reduce the number of iatrogenic lesions, including enterotomy, in the presence of intestinal loops fixed to the anterior abdominal wall. As for researches which are based on studying features of the AIO course in children, the obtained data appeal to greater restraint in surgical treatment of this group of patients.

So, the pathogenesis of the formation of peritoneal adhesions is a complex pathophysiological process, in which a large number of factors are involved and the regulation of which is not fully understood. The results of a large number of proposed methods of adhesions prevention often differ in different experimental groups and models, in addition, none of the means can solve this problem definitively. Many of means are limited by the experimental stage. The amount of data obtained in clinical experiments is not sufficient to recommend these methods for widespread use in clinical practice. To date, the most reasonable and researched preventive strategy is sparing surgical technique and the use of anti-adhesive barrier agents [28, 29, 30, 31].

Conclusions. So, summarizing the literature review, we can conclude that the problem of prevention of excessive intra-abdominal adhesions remains relevant due to the imperfection of the existing variety of methods of prevention and treatment of adhesive intestinal obstruction, and one of the main tasks of its solution in children is to save sparing and effective way of complex prevention of excessive process of intra-abdominal adhesions by way of possible influence on all links of pathogenesis at preoperative, intra- and postoperative stages. 


\section{References}

1. Beyene R.T., Kavalukas S.L., Barbul A. Intra-abdominal adhesions: Anatomy, physiology, pathophysiology, and treatment // Current Problems in Surgery. 2015. - Vol. 52. - P. 271-319. doi: 10.1067/j.cpsurg.2015.05.001.

2. Capella-Monsonís H., Kearns S., Kelly J., Zeugolis D.I. Battling adhesions: from understanding to prevention. // BMC Biomed Eng. - 2019. - Vol.1:5. Published 2019 Feb 27. doi:10.1186/s42490-019-0005-0

3. Kelli M. Braun. The biology of adhesion formation in the peritoneal cavity // Seminars in Pediatric Surgery. - 2014. - Vol. 23. - P. 336-343. DOI: 10.1053/j.sempedsurg.2014.06.004

4. Мельниченко М. Г., Квашніна А. А. Регенерація очеревини та патогенез формування післяопераційних перитонеальних спайок // Хірургія України. - 2019. - № 3. - C. 72-77. [Melnichenko M. G., Kvashnina A. A. Peritoneal regeneration and pathogenesis of postoperative peritoneal adhesions // Surgery of Ukraine. - 2019. - № 3. - P. 72-77]. DOI: http://doi.org/10.30978/SU2019-3-88

5. Fredriksson F., Christofferson R.H., Lilja H.E. Adhesive small bowel obstruction after laparotomy during infancy. // Br J Surg. - 2016. - Vol.103(3). - P. 284-9. doi: 10.1002/bjs. 10072.

6. Okabayashi K., Ashrafian H., Zacharakis E., et al. Adhesions after abdominal surgery: a systematic review of the incidence, distribution and severity. // Surg Today. -2014 . - Vol.44(3). - P. 405-420. doi:10.1007/s00595-013-0591-8

7. Fortin C.N., Saed Gh.M., Diamond M.P. Predisposing factors to post-operative adhesion development. // Human Reproduction Update. - 2015. - Vol.21, No 4. - P. 536551. https://doi.org/10.1093/humupd/dmv021.

8. Кондратович Л.М. Основы понимания формирования спаечного процесса в брюшной полости. Интраоперационная профилактика противоспаечными барьерными препаратами (обзор литературы). // Вестник новых медицинских технологий. - 2014. T. 21, No 3. - C. 169-172. DOI: 10.12737/5929. / Kondratovych L.M. Osnovy ponymanyia formyrovanyia spaechnoho protsessa $\mathrm{v}$ briushnoi polosty. Yntraoperatsyonnaia profylaktyka protyvospaechnymy barernymy preparatamy (Russian). // Vestnyk novykh medytsynskykh tekhnolohyi. - 2014. - Vol. 21, No 3. - P. 169-172.

9. Catena F., Di Saverio S., Coccolini F. et al. Adhesive small bowel adhesions obstruction: Evolutions in diagnosis, management and prevention. // World journal of gastrointestinal surgery. - 201. - Vol. 8. - P. 222-231. DOI: 10.4240/wjgs.v8.i3.222. 
10. Broek R., Krielen P., Di Saverio S. et al. Bologna guidelines for diagnosis and management of adhesive small bowel obstruction (ASBO): 2017 update of the evidencebased guidelines from the world society of emergency surgery ASBO working group // World Journal of Emergency Surgery. - 2018. - Vol. 13. doi: 10.1186/s13017-018-0185-2.

11. Fredriksson, F., Engstrand, T., Christofferson, R.H., Bowden, T., Lilja, H.E. Sutures impregnated with an aldehyde-carbonyl scavenger reduce peritoneal adhesions. J Pediatr Surg. - 2017. - Vol. 52, No 11. - P. 1853-1858. doi: 10.1016/j.jpedsurg.2017.01.058.

12. Gomel V., Koninckx P.R. Microsurgical principles and postoperative adhesions: lessons from the past. // Fertil Steril. - 2016. - Vol. 106, No 5. - P. 1025-1031. doi: 10.1016/j.fertnstert.2016.08.040. PMID: 27692286.

13. Binda M. M. Humidification during laparoscopic surgery: overview of the clinical benefits of using humidified gas during laparoscopic surgery // Archives Gynecology Obstetrics. - 2015. - Vol. 29. - P. 955-971. doi: 10.1007/s00404-015-3717-y.

14. Bamigboye A.A., Hofmeyr G. Closure versus non-closure of the peritoneum at caesarean section: short- and long-term outcomes. // Cochrane Database of Systematic Reviews. 2014. - Issue 8. Art. No.: CD000163. DOI: 10.1002/14651858.CD000163.pub2

15. Cassidy M.R., Sheldon H.K., Gainsbury M.L., et al. The neurokinin 1 receptor regulates peritoneal fibrinolytic activity and postoperative adhesion formation. //J Surg Res. 2014. - Vol. 191, No 1. - P. 12-18. doi: 10.1016/j.jss.2014.04.030

16. Cwaliński J., Bręborowicz A., Połubińska A. The Impact of $0.9 \% \mathrm{NaCl}$ on Mesothelial Cells After Intraperitoneal Lavage During Surgical Procedures. // Advances in Clinical and Experimental Medicine. - 2016. - Vol. 25. - P. 1193-1198. doi: $10.17219 /$ acem/44381.

17. Wu Y., Wei G., Yu J., et al. Danhong Injection Alleviates Postoperative Intraabdominal Adhesion in a Rat Model. // Med Cell Longev. - 2019. - Vol. 19; 2019:4591384. doi: $10.1155 / 2019 / 4591384$.

18. Lee M.T., Lee C.C., Wang H.M, Chou T.H, Wu M.C, Hsueh K.L., Chen S.C. Hypothermia increases tissue plasminogen activator expression and decreases post-operative intra-abdominal adhesion. // PLoS One. - 2016. - Vol. 11, No 9. e0160627. doi: 10.1371/journal.pone.0160627.

19. Wei G., Chen X., Wang G., Jia P., Xu Q., Ping G. Li X. Inhibition of cyclooxygenase- 2 prevents intra-abdominal adhesions by decreasing activity of peritoneal fibroblasts. // Drug design, development and therapy. - 2015. - Vol. 9. - P. 3083-3098. doi:10.2147/DDDT.S80221 
20. Ahmad G., Thompson M., Kim K., et al. Fluid and pharmacological agents for adhesion prevention after gynaecological surgery. // Cochrane Database Syst Rev. -2020. Vol.7, No 7. CD001298. Published 2020 Jul 17. doi: 10.1002/14651858.CD001298.pub5

21. Lim R., Morrill J.M., Prushik S.G., et al. An FDA approved neurokinin-1 receptor antagonist is effective in reducing intraabdominal adhesions when administered intraperitoneally, but not orally. // J Gastrointest Surg. 2008. - Vol.12, No 10. - P. 1754-1761. doi:10.1007/s11605-008-0634-4

22. Jafari-Sabet M., Shishegar A., Saeedi A.R., Ghahari S. Pentoxifylline Increases Antiadhesion Effect of Streptokinase on Postoperative Adhesion Formation: Involvement of Fibrinolytic Pathway. // Indian J Surg. - 2015. - Vol.77, Suppl 3. - P. 837-842. doi:10.1007/s12262-013-1025-y

23. Wu W., Cheng R., das Neves J., et al. Advances in biomaterials for preventing tissue adhesion. // J Control Release. - 2017. - Vol. 261. - P. 318-336. doi: 10.1016/j.jconrel.2017.06.020

24. Chiorescu S., Andercou O., Grad N. O., Mironiuc I. A. Intraperitoneal administration of rosuvastatin prevents postoperative peritoneal adhesions by decreasing the release of tumor necrosis factor. // Clujul Medical. - 2018. - Vol.91. - P. 79-84. doi: $10.15386 /$ cjmed-859.

25. Dinarvand P., Hassanian S. M., Weiler H., Rezaie A. R. Intraperitoneal administration of activated protein $\mathrm{C}$ prevents postsurgical adhesion band formation // Blood. - 2015. - Vol.125. - P. 1339-1348. doi: 10.1182/blood-2014-10-609339.

26. Atta H.M., Al-Hendy A., El-Rehany M.A., et al. Adenovirus-mediated over expression of human tissue plasminogen activator prevents peritoneal adhesion formation / reformation in rats. // Surgery. - 2009. - Vol. 146, No 1. - P. 12-17. doi: 10.1016/j.surg.2009.02.018

27. Weiss A., Sood D., Greenway S.E., Tomassi M. Value of gastrografin in adhesive small bowel obstruction // Langenbecks Arch Surg. - 2017. - Vol. 402(8). - P. 1233-1239. doi: 10.1007/s00423-017-1605-6.

28. Ahmad G., Kim K., Thompson M., et al. Barrier agents for adhesion prevention after gynaecological surgery. // Cochrane Database Syst Rev. - 2020. - Vol.3, No 3: CD000475. Published 2020 Mar 22. doi: 10.1002/14651858.CD000475.pub4

29. Cheong Y., Bailey S., Forbes J. Randomized Controlled Trial of Hyalobarrier ${ }^{\circledR}$ Versus No Hyalobarrier ${ }^{\circledR}$ on the Ovulatory Status of Women with Periovarian 
Adhesions: A Pilot Study. // Adv Ther. - 2017. - Vol.34, No 1. - P. 199-206. doi:10.1007/s12325-016-0453-Z

30. Naito M., Ogura N., Yamanashi T., et al. Prospective randomized controlled study on the validity and safety of an absorbable adhesion barrier (Interceed®) made of oxidized regenerated cellulose for laparoscopic colorectal surgery. // Asian J Endosc Surg. - 2017. Vol.10, No 1. - P. 7-11. doi:10.1111/ases.12334

31. Ten Broek R.P.G., Stommel M.W.J., Strik C., van Laarhoven C.J.H.M., Keus F., van Goor H. Benefits and harms of adhesion barriers for abdominal surgery: a systematic review and meta-analysis. // Lancet. - 2014. - Vol.383, No 9911. - P. 48-59. doi:10.1016/S0140-6736(13)61687-6 